\title{
MIR210 Gene
}

National Cancer Institute

\section{Source}

National Cancer Institute. MIR210 Gene. NCI Thesaurus. Code C81793.

This gene is involved in the regulation of gene expression and plays a role in the development of carcinoma of the breast and acute promyelocytic leukemia. 